\title{
Culture-led urban regeneration policies in the Ibero-American space
}

\author{
Arturo Rodríguez Morató \\ CECUPS/ Department of Sociology, Universitat de Barcelona \\ Barcelona, Spain \\ Matías I. Zarlenga \\ CECUPS-University of Barcelona/ IIAC-Universidad Tres de Febrero \\ Buenos Aires, Argentina \\ Corresponding author: mzarlenga@untref.edu.ar
}

Word count: 9.991

\begin{abstract}
:
This article examines cultural policy strategies supporting urban regeneration, focusing on its particular characteristics in the Ibero-American context. We start by developing a systematic contrast between the different circumstances that have led to the emergence of these strategies in the Ibero-American sphere and in other parts of the world. Our examination of the IberoAmerican regenerative experience also includes a consideration of the paradigmatic cases that arose initially in the Iberian Peninsula and the typological analysis of subsequent Latin American experiences. The consideration of all these different elements ends up providing a global vision of the specificity of the phenomenon in its Ibero-American context.
\end{abstract}

\section{Keywords:}

urban policy; urban cultural regeneration; Ibero-America; Latin America; Barcelona

\section{Introduction}

In recent decades, as a consequence of the general advancement of the post-industrial society as well as the evolution of local politics, cultural activities and the arts have tended to be placed 
at the centre of urban dynamics and governance. In this context, urban cultural regeneration has become a common development strategy for cities all over the world, particularly in the case of old industrial cities needing to renovate their economic basis, and national or regional capital cities aspiring to compete for global centrality (Evans, 2001).

Post-industrial transformation involved an enormous expansion in higher education, the tertiarisation of the economy, as well as the development of corporate capitalism. This was accompanied by deep social changes, which affected the middle classes in particular, a phenomenon that was first visible in America. In Canada and the United States the new conditions gave birth to a new revalorising dynamic of degraded urban areas by the incorporation of a new cultural element: the artists. Motivated by low prices and attracted by the aesthetics of old industrial zones in decline, and by the vitality of the working-class and ethnically-diverse neighbourhoods, artists settle in these areas (Zukin, 1982; Law, 1996; Cameron and Coaffee, 2006). Their presence and their interventions exert an effect of aesthetic transfiguration on the environment, especially when they involve the transformation of old industrial facilities and the development of a new associated lifestyle: Loft living. Once these areas have been culturally revaluated, the new social conditions tend to make them attractive to the middle classes. In the first place, they will attract the "new middle classes", composed of professionals in the media, higher education, design, etc. (Ley, 1996) and later, depending on the effect of real estate capital and on how the material and symbolic transformation of the environment intensifies, as in the case of SoHo studied by Zukin (1982), these areas will also attract other more affluent fractions of the upper-middle classes.

This type of urban cultural regeneration was not based on a policy. It was in this case a bottomup process, in which, spontaneously or led by market forces, culture played a double revalorising role, providing a new pattern of urban consumption to the middle classes and producing the effect of generating a new "cultural landscape". The need for policies of urban cultural regeneration arises later and in another place: in the decade of the 80s, in the context of the entrepreneurial turn of cities in Europe. There, flagship projects began to proliferate at the time often involving the building of major cultural facilities and the organisation of cultural mega events (Bianchini and Parkinson, 1993; Garcia, 2004). In this case, they were top-down processes, led by city halls, where culture appeared as the engine of urban regeneration of historical centers, providing tourism with new types of services in increasing demand (heritage buildings, museums, cultural centres, festivals, etc.).

In later decades, these policies have proliferated and diversified. The formulas aimed at tourism promotion have become more complex and expansive, transforming into cultural branding policies (Evans, 2003). And in parallel, the policies of promotion of creative clusters (Evans, 2009) have also proliferated, which aim to develop the so-called cultural or creative industries (cinema, radio, television), design (web, textile, graphic, industrial), fashion, advertising, photography or architecture.

Since their appearance, urban cultural regeneration policies have received a lot of criticism (d'Ovidio and Rodríguez Morató, 2017). Numerous authors and studies have highlighted their many contradictions, limitations and perverse effects (Pratt, 2011; Scott, 2014). One recurrent complaint is, for example, that cultural regeneration schemes tend to concentrate in specific places, so provoking inequality and polarisation in the city. But undoubtedly the most important criticism is that these policies, oriented to attract professionals, tend to lead to gentrification and correspondingly a loss of authenticity and integrity. In spite of some optimistic managerial views on the issue, the idea that these negative effects are inevitable is largely dominant in the academic world, in particular among urban studies scholars. 
This dominant narrative has mainly been based on the consideration of central cases from the so-called Global North, especially Anglo-Saxons (Toronto, Montreal, New York, London). On the other hand, it has also been based on simplistic views (fundamentally, isolated case studies), which have become generalised without taking into account the importance of contexts. However, when the focus changes to other less central cases (Cameron \& Coaffee, 2006; Markusen and Gadwa, 2010; Stern and Seifert, 2010), or when this focus is broadened by other more complex research designs (Grodach et al., 2014), the perspective is nuanced and diversified, and becomes more positive. Then, a distinction emerges between positive and negative gentrification, the possibility of absence of gentrification appears, and the variability of derivatives according to the types of cultural entrepreneurship is revealed, for example (Grodach et al., 2014).

What does the application of a regional and relatively eccentric perspective, such as the IberoAmerican perspective, contributes to the understanding of the phenomenon of urban cultural regeneration? And why should this particular regional perspective be adopted? Firstly, culturally and historically constituted regions have been considered a propitious base for the production of distinctive patterns of policy outcomes. This is the view provided by the so called "family of nations" concept in policy analysis (Castles, 1993). We want to examine the Ibero-American experience on urban cultural regeneration policies from this perspective in order to ascertain to what extent there is a particular Ibero-American approach to these policies. Secondly, what the Ibero-American experience in this area shows is the importance of using more complex and universal approaches, which recognise the plurality of conditioning contexts or the dynamics of the processes of the deployment of policies in determining the influence that the arts and culture exercise in the urban space. At the same time, this evidence suggests that the influence of culture on urban regeneration can be positive.

In Ibero-America, the phenomenon of urban cultural regeneration responds to the same underlying logic as in other parts of the world. However, in this case the contexts from which it has developed are to a certain extent different from those that have fostered it elsewhere. Thus, the formulas adopted, the contours of the developed processes and the effects achieved have also been to some extent characteristic.

There are two key points to the Ibero-American specificity. On the one hand, the phenomenon has had a somewhat later start in this region than in the Anglo-Saxon world, due to the authoritarian barrier, an impediment that was only fully overcome in the 1980s in the Iberian Peninsula and in the 1990s in Latin America. Its subsequent expansion is framed, thus, within a general democratising wave and is associated with a new local political leadership. On the other hand, another common underlying feature has been the relatively different position that culture has had in these countries: a position marked by a weak legitimacy of high culture, which has largely prevented the development of true gentrifying dynamics in cultural regeneration processes, and which at the same time confer a greater social dimension to culture.

Our analysis will start reviewing the regenerative experience in the Iberian Peninsula, which is a pioneer in the Ibero-American space and we will pay attention, in particular, to two paradigmatic cases: Barcelona and Bilbao. Then, we will consider the Latin American experience, with respect to which we will elaborate a typological analysis based on the cases of Quito, Lima, Salvador de Bahía, Bogotá and Buenos Aires. Finally, we will conclude identifying the most salient common features of urban cultural regeneration processes in Ibero-America.

\section{Urban transformations led by culture in the Iberian Peninsula}


In the Iberian Peninsula, the economic crisis of the mid-1970s had a strong impact on old industrial cities, such as Barcelona and Bilbao. On one hand, here, many areas that hosted industrial activities became obsolete and degraded, while the conditions of the populations that inhabited the historic centres became precarious, leading to the abandonment of the centres and their material and social deterioration. On the other hand, democratic change, which coincided in time with the crisis, delayed the decentralization impulse with respect to the most advanced European countries, but in Spain it also accentuated it from the mid-1980s onwards ${ }^{1}$. This late decentralisation has a peculiar character in the Spanish case, because it incorporated the crucial task of addressing the deficits that had been dragging on since the dictatorship, which gave it a clear sense of democratisation and a predominantly social orientation. The entrepreneurial turn that took place from here on (Harvey, 1989), and the first policies of urban cultural regeneration that emerged as a result, were shaped accordingly, that is, on the basis of a general perspective of social and not only economic character.

Despite a relative delay in the start of cultural policy in Spain, there are processes of urban cultural regeneration that arise in the country at an early stage. These experience an extraordinary development. Two of the main archetypes of urban cultural regeneration at an international level are Spanish: the Barcelona Model and the Bilbao Effect (Evans, 2001; González, 2011). The phenomenon, moreover, is not restricted to these two cases, but includes many others and until the recent crisis did not stop expanding. In fact, in 1992 at the same time that the Olympics were celebrated in Barcelona, Madrid was designated the European Capital of Culture and the Universal Exposition of Seville took place as well. From then on, initiatives of this kind multiplied (Santiago de Compostela became the European Capital of Culture in 2000 and later Salamanca in 2008; the Universal Forum of Cultures of Barcelona in 2004; Zaragoza's Universal Exposition in 2008). The same happened with cultural flagship projects (such as the City of Arts and Sciences in Valencia and the City of Culture in Santiago de Compostela, among many more modest examples). They appeared thanks to the expansive cycle of local cultural expenditure and the policy of building cultural facilities that follow the institutionalisation of the new regional powers, with an orientation towards the enhancement of the cultural offer and a predominant inclination towards tourism. In this context, with the general proliferation of schemes of urban cultural regeneration of different sizes and dimensions, the cases of Barcelona and Bilbao stand out for their size and vast success. Others appear, such as Valencia or Santiago de Compostela, of similar ambition, but are poorly planned, less original and less successful.

In Portugal, urban cultural regeneration projects have been scarce, due to the late decentralisation of the country, and have largely followed the steps of previous Spanish experience. Apart from Lisbon, which celebrated becoming the European Cultural Capital in 1994 and four years later, a Universal Exposition in 1998, the only other significant case is that of Porto, which in 2001 was also the European Capital of Culture and built, within the framework of this programme, an emblematic cultural institution: A Casa da Música (Ramalho, 2012).

Contrasting the Spanish and Portuguese experiences, the role played in Spain by regional competition, conferring political importance to the initiatives of the autonomous governments, stands out as the key differential factor. In the following sections we will consider the cases of Barcelona and Bilbao, since, due to their virtuous originality and maximum projection, they are the most significant. Then, we will reflect on these Iberian models in a comparative perspective trying to identify their common traits.

\footnotetext{
${ }^{1}$ In Portugal, on the contrary, this impulse will not come until the end of the 1990s and will be much less intense.
} 


\section{The case of Barcelona}

Barcelona is an exemplary case for multiple reasons. First of all, because of its outstanding success. Barcelona's transformation, particularly that which took place from the mid-1980s until the 1992 Olympic Games, was almost unanimously considered as exemplary (Evans, 2005: 968). There was a deep change in the international image of the city from the Olympic Games and the city's tourist attraction has not stopped growing since then (in the last decades, Barcelona has been the European city whose tourism has grown the most, having gone from 1.7 million visitors in 1990 to 8.3 million in 2015). From the time of the Olympics, the creative and avant-garde reputation of the city has also been established in multiple fields, from architecture and design to high cuisine and electronic music (Rodríguez Morató, 2008). This success was based, to begin with, on some specific conditions that were largely favorable to change. On the one hand, it was based on a long entrepreneurial tradition in the city, which started in the $19^{\text {th }}$ century and lasted throughout the $20^{\text {th }}$ century, a tradition that goes back to the two Universal Expositions held in Barcelona, in 1888 and 1929. On the other hand, it also had to do with the important cultural base of the city, in particular, in urban and architectural terms (Subirós, 1993). The combination of both traits produced a sustained and increasingly intense commitment to culture as a tool for the development and cohesion of the city, giving rise to a virtuous model of urban cultural regeneration which in the last decades has had an enormous influence worldwide (González, 2011).

Barcelona's cultural regeneration model is very complex. It has multiple dimensions. Over the years, Barcelona has used cultural activity or urban design for the transformation of citizen relations (relationships between neighbourhoods, relationships among people, uses of the city, citizen engagement, participation and inclusion); also, in an especially intensive way, to change the international image of the city, in order to gain global reputation and to attract tourism and investment. The cultural institutions and professional and industrial sectors responsible for cultural production have been considered strategic areas for the socio-economic development of the city and promoted as such. Likewise, in an interrelated way, they have also been used as a resource for the urban revival of different areas of the city, sometimes in a concentrated way, in certain points or clusters and other times in a more dispersed way. Above all, the city has specialised in the production of cultural mega-events, which have served to encompass and enhance many of the previous interventions and have also served to attract extraordinary economic resources to the city and enhance local leadership. From these experiences, finally, a more general specialisation has been derived in the production of events, which has led to a successful eventification of the city (Richards, 2015). Moreover, all of this diversity of regenerative cultural actions has been conveyed within different governance arrangements (involving more or less consensus) and through very diverse management schemes: sometimes from public-private partnerships of various kinds and often from strategic planning mechanisms.

On the other hand, the model has undergone multiple transformations and it is therefore not easy to appreciate continuity. From the point of view of urban planning, the model takes shape in two successive stages, which are relatively heterogeneous: first, through micro-urbanistic operations in the recovery of public spaces, at the beginning of the 1980s, and second, of more far-reaching interventions in relation to the Olympic Project (Monclús, 2003). From that time, however, it does not vary substantially. On the contrary, from a viewpoint focused on governance, the two previous stages maintain continuity, but from the mid-1990s a change of orientation took place that began to erode the participatory consensus on which municipal action was based until then (Degen and García, 2012). From the perspective of the intersection between cultural action and urban development, it could be said that in the mid-1990s two contradictory changes took place, which have altered the interlacing formula in force until then, and led to increased tension. First, a change in the management of the municipal cultural policy 
accentuates its autonomy, which tends to separate it from the concerns for urban regeneration. Second, an increase in the importance and centrality of culture within the strategic development of the city drives it in an opposite direction, towards the assumption of the cultural leadership of urban transformation (Rodríguez Morató, 2008).

The literature on the Barcelona Model is extensive and varied (Marshall, 2004; Degen and García, 2008; Blanco, 2009). Given the complexity of the model, there are mostly partial visions (Monclús, 2003), which therefore have difficulties capturing the relationship between the urban, cultural and social dimensions of the phenomenon, which is precisely the key to it. The definitions of the model derived from them are also varied and inconclusive ${ }^{2}$. Here we will briefly consider two characteristic processes within the general strategy, which will be more useful in order to give an idea of the Barcelona model and will help us better characterize the features of urban cultural regeneration in the Iberian Peninsula.

The processes that we are going to consider in the following are arguably the two most archetypical regenerative processes in Barcelona: the process of urban aestheticisation that took place in Barcelona from 1980 to 1992, in the context of the organisation of the 1992 Olympic Games, and the culture-led regeneration and subsequent conversion of El Raval in a cultural quarter, a process that started at the same time and lasted until the beginning of the new millennium.

\section{The 1992 Olympic Games' urban renewal}

A very successful aesthetisation of Barcelona took place between 1980 and 1992, in the process of preparing for the Olympic Games, characterised by the strong public leadership of the council and in particular by the leading role of municipal architects. A crucial moment was the founding in 1980 of the Urban Projects Department at the Barcelona Council, which from the beginning assumed the whole responsibility of urban design. The "unitary project" was the master formula. The idea was that the project -any urban public project- should be put under the responsibility of an architect-as-author. Projects were undertaken in functionally debased spaces or in non-urbanised spaces of the periphery, so all across the city (Subiros, 1993). These projects consisted, in a first phase, in the creation of new squares, the removing and substitution of obsolete buildings or premises and the opening of new parks and gardens. These kind of projects, typically included modern urban furniture, specifically created for the place, significant elements of memory (a chimney of a disappeared factory, for example) and contemporary sculptures (usually created for the place). In a second phase (1987-92), these urban interventions included global projects that involved the whole city. Artistic urbanism arose from this unitary project and was applied to the four large Olympic areas, strategically situated in peripheral areas of the city that needed renovation. The conception of the large infrastructural projects also took into account the formal and cultural urban logic.

The transformation got an outstanding international recognition in architectural circles. It was characterised by its public leadership, by having been conceived in a holistic way, affecting all parts of the city and by having followed a plan carefully designed and informed by citizens voices. But most of all, it was characterised for its strong aestheticist emphasis, which transcended the planning action of the city council and included many other "layers of design activity and consumption", both public and private (Julier, 2005: 875). This aestheticist element was very important in citizens' identification with urban transformation (very high at that moment) and

\footnotetext{
2 Thus, for example, Sanchez Belando et al. (2012: 37) restrict it to three characteristics while Arbaci and Tapada-Berteli (2012: 291) identify no less than 10 traits and just one of them is part of the other list.
} 
in their widespread mobilisation. An index of this mobilisation was the huge success of a modest city council campaign for the restoration of buildings, "Barcelona, posa't guapa" (Barcelona, get beautiful), launched in 1986, which involved small public subsidies. Within ten years with the involvement of the media and an important part of citizenry this campaign completely changed the façade aspect of the city (Ferrer Viana, 2001). For the rest, the aestheticist element has also been crucial in promoting Barcelona's image abroad and attracting tourists. In this way, the city has been recognised as the most paradigmatic example of a successful design-led urban regeneration city (Julier, 2000; Bell and Jayne, 2003).

\section{Culture-led regeneration of a decayed neighborhood: El Raval}

El Raval is a central quarter of Barcelona that in the 1970s experienced a number of critical social problems (high unemployment, poverty, drugs, crime), in addition to having poor living conditions in old and deteriorated buildings. In 1987, the new democratic city council developed plans for changing this situation, which has comprised of two kinds of interventions: first, an urban renewal plan, mostly funded by the European Union, that involved the restoration of housing, the opening of public spaces, and the improvement of urban furniture (Gomà and Rosetti, 1998); and second, a cultural regeneration strategy consisting in the location there of the CCCB (Barcelona Centre for Contemporary Culture), in a brilliantly transformed ancient building, and the MACBA (Barcelona Museum of Contemporary Art), in a new construction by the prestigious American architect Richard Meier, plus some university schools and other thirdsector cultural institutions.

The result of these interventions, which culminated in the early 2000s, was not the expected cliché of gentrification (Subirats and Rius, 2006). Two unplanned factors contributed especially to this. First, the evolution of the main cultural institutions in the neighbourhood did not attract too many tourists and it only marginally and temporarily attracted some gallerists. Secondly, in parallel with the previous process, the quarter received a large number of poorer immigrants and became the most multicultural quarter in Barcelona. This new population strongly reinforced the lower-class profile of the quarter, which made it difficult for gentrifiers to settle there. By the same token, however, El Raval also underwent a process of symbolic accumulation, attracting artists and cutting-edge creative activities and increasing the reputation of the neighbourhood's cultural institutions (Rius, 2008). So, in the end El Raval became a true cultural quarter, following an unexpected path, including contradictions and involving unforeseen actors, whilst avoiding gentrification ${ }^{3}$.

\section{The case of Bilbao}

Culture was never at the centre of Bilbao's revitalisation plan, which predates the project to install a branch of the Guggenheim Museum in the city and had a predominant economicindustrial dimension (del Cerro, 2006). Beatriz Plaza, who attempted to present the "whole image" of the revitalising effort, emphasised in this respect that the museum, like the other cultural initiatives that accompanied it, was "an integral part of a larger coherent public policy

\footnotetext{
${ }^{3}$ There is an abundance of critical literature that over the years has been denouncing the gentrification of El Raval, but their perspectives on the phenomenon have been generally quite limited (see Rius, 2014: $14-15$, note 1). On the contrary, Subirats and Rius (2006) documented in depth the fundamental social continuity of the neighborhood during the first twenty years of its transformation, which allows us to conclude that the the regenerating operation has not produced any significant gentrification in terms of class replacement.
} 
targeted at productivity and diversity"; in fact, it constituted" the icing on the cake "(Plaza, 2008: 9).

The urban regeneration operations themselves had, on the other hand, two main phases (González 2006). The first, in the early 1990s, was centred on physical regeneration (the clean up of the estuary, moving the port towards the sea, freeing up key central inner-city areas, and the construction of the underground system), even if an important aestheticist element was already integral to this phase from the start. All the operations carried out had "an intense regard for aesthetics and design" (Gómez, 1998: 113), including the building of the subway whose stations were designed by Norman Foster.

In the second phase, developed from the late 1990s to the early 2000s, the symbolic element, in the form of city marketing and architectural flagships, became even more prominent and incorporated emblematic cultural contents, such as the Guggenheim Museum, designed by Frank Gerhy, which was inaugurated in 1997. This was followed by inaugurations for the Euskalduna Palace for music and congresses in 1999, one for the new airport designed by Santiago Calatrava in 2000, one for the Abandoibarra project (flagship regeneration project in the former inner city shipyard commissioned to Cesar Pelli) in 2003, that of the new Exhibition Fair in 2004, the set of residential towers designed by Isozaki in 2006 and finally that of the Zorrozaurre Project (the regeneration of a derelict river peninsula by Zaha Hadid) in 2007 (González, 2006: 845).

This second phase, on the other hand, is still prolonged in a third phase, involving the general strengthening of the Bilbao cultural sector (Plaza et al., 2009) and the cultural revitalisation of degraded central districts, such as those of Bilbao La Vieja and San Francisco (Vicario and Martínez Monje, 2003; Gainza, 2017), recently promoted as artistic neighbourhoods.

\section{The Guggenheim Museum Bilbao's effect}

From the beginning, the constitution of the Guggenheim Museum franchise in Bilbao (GMB), created in an extremely opaque manner by the Basque regional government and without taking into account the the cultural sector opinion (Zulaika, 1997), provoked criticism and resistance. Soon, however, their success was shown in terms of tourism attraction and the positive impact on the image of the city abroad and on the pride and optimism of the citizens ${ }^{4}$. Changes produced in this respect were so obvious that critics had no choice but to recognise them (Gómez and González, 2001). However, distrust persisted with respect to the capacity of the GMB, first, to revitalise the city's economy, second, to compensate for the large amount of investment it initially entailed (to the detriment of other needs of the cultural sector, as pointed out by Zallo, 1995), third, to sustain its attraction as a tourist magnet over time, and fourth, to promote the productive capacity of the cultural sector in the city.

Throughout the years, Beatriz Plaza has been providing evidence and analysis that have clarified the previous aspects, offering a balance of the operation that at this point appears as clearly positive. To begin with, it has already been said that the GMB operation was never intended to be the exclusive or even primary lever of the Basque economic recovery (Plaza 2008). Its fundamental objective was rather to promote a global and positive image of Bilbao, an objective whose achievement all analysts have unanimously recognised. On the other hand, public investment on the part of the Basque institutions to launch the GMB was certainly very large

\footnotetext{
${ }^{4}$ Visitors to the city passed from 100,000 per year before its opening to more than 900,000 the following year (Plaza, 2008: 506)
} 
( $€ 159$ million). But Plaza (2006) demonstrated that this original investment was covered in less than ten years thanks to the vast impact on tourism and the positive effect on employment generated by the project, which was a record. In the third place, twenty years after GMB's inauguration, it can be assured that its tourist attractiveness does not decline but remains firm and stable ${ }^{5}$. In this sense, the conversion of Bilbao into a tourist city definitely seems assured. Finally, Plaza et al. (2009) and Plaza and Haarich (2015: 1466) have documented the links that the GMB has established with the institutions and agents that make up Bilbao's cultural sector and the significant effects that its creation has had on them (through boosting art-supporting policies in the city or bringing about the diversification, spacial structuration and upgrading of Bilbao's art scene). All these achievements have made the GMB "the paradigmatic case of a cultural flagship artifact put forward to revitalise a city's urban and economic fabric" (Plaza et al., 2009: 1711).

\section{Contrasting the Iberian culture-led regeneration models}

The regenerative models of Barcelona and Bilbao have been marked by characteristic and differential initiatives. Bilbao's model was marked by a flagship cultural artefact, whilst Barcelona's model relied on a cultural mega-event. But in both cases the formula is similar in some fundamental ways. In both, for example, these initiatives are the result of the entrepreneurial thrust of the territorial public administration (in Bilbao, this thrust came from the regional and provincial administration, while in Barcelona, it came from the city council). And in both, the project is formed on the basis of an established brand and an international organisation, with an important reputation. The project comes, thus, to consist of the original and virtuous execution of a script previously defined and loaded with reputational value.

At the same time, the regenerative models of Bilbao and Barcelona have a similar urbanistic component of an aesthetic character, which incorporates high-quality architectural works, most of them designed by star architects. However, it must be said that the type of urban intervention developed in both cities was not equivalent, especially at the beginning. The Bilbao intervention, promoted by a nationalist regional administration, concentrated on abandoned industrial spaces near the centre of the city and took as a point of reference the spectacular and privatising North American urbanism (Hall, 1990; Sarfatti Larson, 1995). On the contrary, Barcelona's intervention, carried out by a local left-wing government, was conceived on the basis of social democratic parameters and with a perspective that encompassed the entire city. For the rest, the regenerative trajectory of both cities ended up incorporating similar elements. The Barcelona urban development operation linked to the Forum, from the beginning of the 2000s, will be very similar to Bilbao's urban operation in Abandoibarra. In Bilbao, the regenerative concentration on the abandoned areas will give way to a greater attention on some areas of the city centre. And there, in the neighbourhood of San Francisco, for example, the regeneration experience will be comparable to the one in El Raval (Gainza, 2017). Therefore, the results of the regenerative process will be, in the end, quite similar, even though the elements of the process have appeared in each case in a different order.

As a whole, then, despite their significant differences, the cultural regeneration models that represent both cities also show important similarities. We synthesise them in the following table.

Figure 1: Urban cultural regeneration landmarks in the Iberian Peninsula: common traits

\footnotetext{
${ }^{5}$ It has even grown slightly in recent years, having produced the record in attracting the public from outside the Basque Country in 2017, with 1,047,000 visitors.
} 


\begin{tabular}{|c|c|}
\hline $\begin{array}{l}\text { Organisational } \\
\text { dimension }\end{array}$ & $\begin{array}{l}\text { Top down. Public leadership of a local character with important private participation } \\
\text { and complex governance. } \\
\text { Participation and inclusion schemes that are variable but always important (they start } \\
\text { being more intense in Barcelona but tend to deteriorate later while in Bilbao they } \\
\text { follow a reverse path). } \\
\text { Careful strategic planning. }\end{array}$ \\
\hline $\begin{array}{l}\text { Urban } \\
\text { dimension }\end{array}$ & $\begin{array}{l}\text { Urban centric/polycentric. Territorial schemes of regeneration are initially contrasted } \\
\text { but then tend to be polycentric (they are characteristically polycentric from the } \\
\text { beginning in Barcelona and initially centralist in Bilbao). }\end{array}$ \\
\hline $\begin{array}{l}\text { Cultural } \\
\text { dimension }\end{array}$ & $\begin{array}{l}\text { Culture as a heritage asset oriented towards tourism and citizens and culture as a } \\
\text { shared representation. Both produce aesthetisation and branding. } \\
\text { Schemes of contents and configurations tend to be plural and complex, combining } \\
\text { consumption and production, the local and the global, the old and the new; and they } \\
\text { interlace with other dimensions like the social or the political (Barcelona clearly leads } \\
\text { this trend, but Bilbao progressively adopts the same parameters). }\end{array}$ \\
\hline
\end{tabular}

Source: Own Elaboration

\section{Cultural led urban regeneration in the Latin America space: heritage revitalisation, civic transformation, and creative regeneration}

Cultural led urban regeneration started to be a relevant policy issue from the beginning of the 1990s in Latin America (Hernández, 2013; Kanai \& Ortega-Alcázar, 2009; Lacarrieu, 2010; Yúdice, 2008). It is possible to distinguish at least four reasons that explain this emergence. Firstly, a deterioration of historic centres and old industrial and port areas of a large number of Latin American cities. Non-controlled urban expansion from the 1950s, and the deindustrialisation process from the 1970s, added to social inequality, and ended up defining areas of action of cultural led urban regeneration policies in a broader and more diverse way than the Anglo-Saxon and European experiences. Secondly, the democratisation and decentralisation processes from the 1980s to 1990s also played an important role in the emergence of cultural led urban regeneration policies (Boisier, 2004; Montero \& Samuels, 2004). Finally, the policy transfer processes between Iberian and Latin American countries from the 90 s also contributed to exchange experiences of urban cultural revitalization projects, where the Spanish influence has been relevant (González, 2011). These policies were oriented towards urban revitalisation, social and citizen inclusion and economic development, where culture has always played a key role.

Within this frame, it is possible to distinguish at least three types of culture led urban regeneration public policies in Latin American cities from the beginning of the 1990s until the present: (1) Policies which aim to generate cultural services for tourist attraction through the recovery of buildings and urban heritage in Latin American historical centres. (2) Policies that aim to promote social inclusion and combat poverty through building a sense of citizenship. (3) Policies that aim to promote local economic development -as a key element for urban revitalisation- through the creation of cultural and knowledge industry districts in old industrial zones.

In this section, we develop a typology that aims to characterise the different orientations and modalities of cultural led urban regeneration public policies in Latin America from the 1990s to the present. We argue that three types of cultural led urban regeneration public policies exist in Latin American cities: heritage revitalisation, civic transformation, and creative regeneration. 
The typology of cultural led urban regeneration public policy was designed considering the following three dimensions: the urban dimension (related to intervened urban areas), the organisational dimension (related to the political, economic and social aspects of the policies) and the cultural dimension (related to the uses and meanings of culture). The case studies selected to design our typology were: the Historical Centre's Heritage Recovery Plans from Quito, Lima and Salvador de Bahía at the beginning of the 1990s; the Citizen Culture Programme implemented in Bogotá in 1995; and the Cultural District Plan implemented in the southern zones of Buenos Aires between 2008 and 2015 (See Figure 1).

Figure 2: Typology of cultural led urban regeneration policies in the Latin American space

\begin{tabular}{|c|c|c|c|}
\hline & Heritage revitalisation & Civic transformation & Creative regeneration \\
\hline Definition & $\begin{array}{l}\text { Economic type of public } \\
\text { policy of cultural led urban } \\
\text { transformation based on } \\
\text { the building and urban } \\
\text { heritage recovery of Latin } \\
\text { American historic city } \\
\text { centres for tourist } \\
\text { exploitation. }\end{array}$ & $\begin{array}{l}\text { Social type of urban } \\
\text { cultural transformation. } \\
\text { Public policy based on } \\
\text { the construction of a } \\
\text { civic culture through } \\
\text { cultural interventions. }\end{array}$ & $\begin{array}{l}\text { Economic type of cultural led } \\
\text { urban transformation public } \\
\text { policy based on the creation } \\
\text { of cultural districts for urban } \\
\text { regeneration through } \\
\text { economic development. }\end{array}$ \\
\hline Cases & $\begin{array}{l}\text { Quito, Lima, Salvador da } \\
\text { Bahía }\end{array}$ & Bogotá & Buenos Aires \\
\hline $\begin{array}{l}\text { Urban } \\
\text { dimension }\end{array}$ & $\begin{array}{l}\text { Urban centric. Historic } \\
\text { centres (historical } \\
\text { buildings, public spaces, } \\
\text { etc.). }\end{array}$ & $\begin{array}{l}\text { Urban polycentric. City } \\
\text { inhabitants and urban } \\
\text { public spaces: streets, } \\
\text { parks, avenues, traffic, } \\
\text { etc. }\end{array}$ & $\begin{array}{l}\text { Urban centric/polycentric. } \\
\text { Old industrial and port areas } \\
\text { of cities. }\end{array}$ \\
\hline $\begin{array}{l}\text { Social } \\
\text { Dimension }\end{array}$ & $\begin{array}{l}\text { Top down. Local } \\
\text { administration centrality } \\
\text { based on a complex set of } \\
\text { collaborations, } \\
\text { dependencies and tensions } \\
\text { with the rest of the } \\
\text { intervening social actors } \\
\text { (from the private and } \\
\text { socio-community sectors). }\end{array}$ & $\begin{array}{l}\text { Top down. Local } \\
\text { administration } \\
\text { centrality based on a } \\
\text { relationship of } \\
\text { interdependence with } \\
\text { citizens and the media. }\end{array}$ & $\begin{array}{l}\text { Top Down. Local } \\
\text { administration centrality } \\
\text { based on the collaborative } \\
\text { relationships and the } \\
\text { dependency on the private } \\
\text { sector and tensions and } \\
\text { conflicts with the socio- } \\
\text { community sector. }\end{array}$ \\
\hline $\begin{array}{l}\text { Cultural } \\
\text { Dimension }\end{array}$ & $\begin{array}{l}\text { Culture as a heritage asset } \\
\text { oriented towards tourism. } \\
\text { Culture as an } \\
\text { activity/cultural service for } \\
\text { the attraction of visitors } \\
\text { and tourists. } \\
\text { Culture as cultural facilities } \\
\text { for tourist attraction. } \\
\text { Consumption orientation. }\end{array}$ & $\begin{array}{l}\text { Culture, in a semiotic- } \\
\text { anthropological sense, } \\
\text { representing a sense of } \\
\text { belonging and shared } \\
\text { codes of meaning. } \\
\text { Culture as an } \\
\text { instrument of } \\
\text { intervention through } \\
\text { the arts, as a tool for } \\
\text { the construction of a } \\
\text { new citizenship. }\end{array}$ & $\begin{array}{l}\text { Culture as a sector of activity } \\
\text { to be promoted. } \\
\text { Culture as urban facilities for } \\
\text { attracting talent. } \\
\text { Culture as creativity for the } \\
\text { sustainable development of } \\
\text { cities. } \\
\text { Production orientation. }\end{array}$ \\
\hline
\end{tabular}

Source: Own Elaboration

\section{Heritage revitalisation}

Heritage revitalisation is understood as economically oriented public policy of cultural led urban transformation, based on the building and urban heritage recovery of historic city centres for tourist exploitation that gained relevance from the 1990s in several Latin American cities. Historic city centre heritage recovery plans from Quito, Lima and Salvador da Bahía were 
selected as case studies both due to the importance of their architectural and urban legacy and their selection as world heritage sites by UNESCO.

Many scholars point out the relevance of heritage revitalisation policies during the 1990s, due to the effects of the state decentralisation process that affected most Latin American countries (Luque Azcona \& Smith, 2010, p. 306; Mutual, 2001, p. 122; Ronda, 2000, p. 88). State decentralisation gives local government political, administrative and budgetary autonomy for the implementation of heritage revitalisation policies. In this sense, the authority of the design, implementation and control of heritage revitalisation policies in Latin American cities tended to be local public administration via public urban and cultural dependencies, Special Administrative Units (such as Administración Zonal in Quito and Prefeitura Municipal and the Instituto de Patrimonio Histórico y Artístico Nacional, IPHAN in San Salvador de Bahía); public institutions created ad-hoc with heritage purposes (such as PROLIMA in Lima); etc.

Many scholars also highlight the "political will" [voluntad política] of mayors (such as Alberto Andeade, the charismatic Mayor of Lima) to achieve heritage revitalisation goals (Ronda, 2000). In contrast to Iberian models of revitalisation -mostly focused on the creation of large cultural facilities (such as flagship buildings and museums) or big events as a central aspect of regeneration policies- heritage revitalisation policy in Latin American historic centres focused on the protection and rehabilitation of historic buildings for housing (minority), shops and hotels oriented to tourism (majority). This kind of intervention was expanded to similar action in the urban areas of historic centres, such as through the recovery and enhancement of squares; the improvement of urban infrastructure (lighting, historic monuments, accessibility, improvement of streets and sidewalks); the relocation of itinerant commerce; and the accessibility programmes for social housing (Carrión, 2001; Gutman, 2001; Mutual, 2001). Like many cities in Spain in the 1980s, small festivals and cultural activities were used as complement mechanisms to attract visitors and tourists to revitalise historic centres. Festivals for local residents, as well as tourists, were used to promote historic centre visiting by local administration in Quito and Lima (Dias Velarde, 2001). In Salvador da Bahía, for its part, programmes of fiscal incentives to culture were implemented for the production of shows and programmes of socio-cultural animation aimed at tourism (Luque Azcona \& Smith, 2010).

The centrality of the public sector in this kind of initiative defines the process of heritage revitalisation as top-down, based on a complex set of collaborations, dependencies and tensions with the rest of the intervening social actors (private and socio-communitarian sectors and inhabitants) (Caraballo Perichi, 2001). Open conflicts between local and central administration can be observed in the heritage revitalisation process during the 1990s. In this regard, this situation of conflict between administrations (local and central) is observed through a clash of interests among the SPHAN (national), IPAC (state) and the Prefeitura (local) for the control of the renovation process of the historic centre of Salvador da Bahía (Luque Azcona \& Smith, 2010). In the frame of this rehabilitation, this is also observed, in a more open way, in the confrontation between national police (dependent on central power) and municipal police (dependent on local power) for the relocation of informal street trade on the streets around the Lima's central market (Ronda, 2000).

The relationship between public and private sectors in heritage revitalisation policies has varied depending on the way in which the private sector participates in these kinds of processes. Where the processes were led and executed exclusively by the public sector, the intervention of the private sector is smaller, limited to investments in shops and hotels oriented to tourism, as in the case of Salvador de Bahía (Luque Azcona \& Smith, 2010). Where leadership and execution were shared between public and private sectors, there is an alliance that is crystalised in publicprivate partnerships, such as the "Empresa del Centro Histórico" [the Historic Downtown 
Company] in Quito. Beyond these differences, it is possible to characterise a social tie between the public and private sector in heritage revitalisation policies as indirect mutualism. On the one hand, the private sector (real estate and agents linked to the provision of tourist services) has usually benefitted from urban infrastructure revitalised by the public sector. On the other hand, the investment made by the public sector in building and urban revitalisation is expected to become sustainable over time through private investment aimed at providing tourism services.

The relationship between public and socio-communitarian sectors in heritage revitalisation processes has had two sides. On the one hand, there has been a conflict with informal commerce and residents belonging to the popular and low-income sectors due to their relocation, in the frame of the recovery of public spaces and the re-habilitation of buildings, which enabled many scholars to interpret these processes in terms of gentrification (Betancur, 2014; Janoschka, Sequera, \& Salinas, 2014). In this line, it is possible to identify a conflict between local administration and informal traders for their relocation in the cases of Quito and Lima. Also, a conflict between IPAC and the Movement of Defesa dos Favelados (the historic building squatters and roomers movement affected by the policy of relocation for the preservation of the historic buildings where they lived) for fairer compensation in Salvador da Bahía (Luque Azcona \& Smith, 2010). On the other hand, there were public sector initiatives aimed at directly encouraging citizen participation in rehabilitation processes. An example includes citizen mobilisation policies in the regeneration plan for the city of Quito, through institutional coordination, the promotion of civil society initiatives and mechanisms for assessing the awareness of the value of the historic centre and its use (Moreira Ortega, 2001); or the participation of civil society organisation in the conservation policies (such as the initiatives of Patronato de Lima) (Dias Velarde, 2001).

At least three cultural meanings can be drawn out from heritage revitalization policies. Firstly, culture appears as a patrimonial asset oriented towards attracting tourism. This sense of culture was instrumented by policies of recovery and the functionalisation of historic buildings, such as commercial and hotel facilities. Secondly, culture appears as a type of activity or service for the attraction of visitors and tourists. This was instrumented by policies of promotion of musical groups and dance; development of craft professions and festival organisation in order to make historical centres more visible and attractive to tourists and visitors. Finally, culture appears as cultural facilities. Art museums and galleries were built as part of tourist attractions, especially in the case of Salvador da Bahía.

\section{Civic Transformation}

Civic transformation is understood as a social type of urban cultural transformation policy based on the construction of a civic culture through cultural interventions. The Citizen Culture Programme [Programa de Cultura Ciudadana] implemented in Bogotá is the paradigmatic example of this type of urban public intervention. The Programme transformed the city by the modification of the moral behaviour of their citizens (Hernández, 2013; Pasotti, 2012; Yúdice, 2008).

The implementation of civic transformation policies, as in the case of heritage revitalisation, were carried out by the local government (top down). The Bogotá case was driven by the charismatic figure of their mayor, Antanas Mokus, and implemented by a body of professional experts. The regulatory framework that defines civic transformation in this case was the "Plan integral del Desarrollo del Distrito Capital" [the Capital District's Development Plan], based on the Citizen Culture Programme (1995-1997) (Pasotti, 2012). 
As with heritage revitalisation, the civic transformation policy implemented in Bogotá was made possible thanks to the process of state decentralisation. In 1986 state decentralisation policies allowed for the direct election of mayors (prior to this the mayors were elected by the governor and the mayor of Bogotá by the president). This led to the proliferation of independent candidates to compete for mayoral offices in 1991 (a result of the weakness of traditional Colombian parties). In turn, mayors gain important competences in terms of financial resources. This new situation is due, on the one hand, to the possibility of removing former city councillors from public service companies (where the largest amount of public resources is concentrated). On the other hand, it is due to a tax reform that increases the income of the city. Within this framework of political and fiscal reforms, Antanas Mockus is elected mayor of Bogotá in 1994 by a coalition of independent parties.

It is possible to distinguish at least three phases in the implementation of the Citizen Culture Programme. The first was the empirical survey, based on the investigation of the living conditions of citizens, the existing justice initiatives and the proposals of revitalisation of the public space. A second moment of intervention was based on the empirical evidences collected in the first phase. The interventions consisted of artistic performances in public spaces in the city, aiming to generate disruptions of the common order and open a space for reflection. It was hoped that the "moral emotions" provoked by artistic-cultural actions would become a fundamental instrument to achieve the purposes of building citizenship. A third moment was characterised by the diffusion of the public artistic interventions by the media, as a complement to the Citizen Culture Plan. The interventions carried out were counterintuitive, leading them to become news in the media and spread across the city (Pasotti, 2012; Yúdice, 2008).

Civic transformation policy, implemented in the Citizen Culture Programme, was characterised by a relationship of interdependence between the public sector, citizens and the media. Public actions were initiated from the local government and replicated by the citizens through the media. Within this process, the media became a communication tool to build on the new role of citizenship. In this sense, the media fulfilled a function of broadening the actions implemented by the local government, participating indirectly in the construction of a new citizenship. This situation generated a symbiosis between the government and the media (Pasotti, 2012).

Culture was understood both as a "way of life" (in a semiotic-anthropological sense) and as an "instrument of intervention" (a set of public artistic performances) in the civic transformation policies implemented through the Citizen Culture Programme. This means that culture was understood, on one hand, as a sense of belonging and shared codes of meaning that participate in the construction of citizen morals. But, at the same time, culture functioned as an instrument of intervention through the arts, as a tool of change and modification of behaviour to construct a new citizenship.

\section{Creative Regeneration}

Creative regeneration is understood as an economic type of cultural led urban transformation based on the creation of cultural districts for urban regeneration through economic development in old industrial areas of cities. These types of policies are usually based on the paradigm of creative cities (Landry, 2008; Landry \& Bianchini, 1998), that emerged in many Latin America cities from the middle of the 2000s. Buenos Aires is a relevant case when trying to understand this kind of policy in Latin America, due to its policy of setting cultural districts (art districts, design districts, audiovisual districts and technological districts), with urban regeneration and economic and social development purposes (developed from 2007) (Thomasz, 2016; Zarlenga \& Marcus, 2014). 
Creative regeneration public policies, like heritage revitalisation and civic transformation policies, are designed and implemented by local government [top down] (usually by economic development, urban planning and cultural public dependencies), but in association with the private sector. Buenos Aires' District Master Plans, for example, were designed and implemented by the Sub-secretariat of Creative Industries, under the Ministry of Economic Development (Implementation Authority), associated with Metropolitan Centres (public facilities for promotion, advice and assistance for companies) and the DG of Creative Industries in collaboration with the Ministry of Culture of Buenos Aires.

This kind of creative regeneration policies are usually implemented by a series of actions such as: (1) Zoning: Delimitation of urban areas for the establishment of companies and ventures linked to the arts, creative and knowledge industries. (2) Tax incentives and credits for the private sector to invest and settle their economic activities in the district. (3) Public investment in urban infrastructure: improvement of public spaces and the creation of public facilities for creative industries and knowledge promotion. (4) Promotion of private investment: especially real estate projects. (5) Generation of synergies between the public sector, educational institutions, the private sector and NGOs. (6) Use of creativity as a tool to encourage development at the local level (Thomasz, 2016).

The centrality of the public sector defines creative regeneration policies as a top-down policy based on collaborative relations and dependencies with the private sector, and tensions and conflicts with local residents and socio-community based organisations. Within the public sector, there are collaborative relationships between different ministerial agencies driven by the goal of district policy. In the case of the city of Buenos Aires, collaborative relationships between the Ministry of Economic Development and the Ministry of Culture can be observed in the 20122014 Action Plan.

The relationship between local administration and the private sector framed in creative regeneration policies can be characterised as attraction and dependence. On the one hand, private companies and ventures are attracted by the public sector via tax incentives installed in urban areas defined by district policies. On the other hand, it is expected that the investment and economic development generated by the companies and ventures installed revitalise the urban area. Initially, there is public sector leadership in revitalisation (via urban infrastructure improvement, the creation of public facilities and the attraction of companies). Subsequently, the private sector is expected to lead urban revitalisation through the economic development of its activity.

The relationship between public sector and socio-community-based cultural organisations, social movements and the inhabitants of urban areas affected by the creative regeneration policy has two faces. On the one hand, there are relations of tension and conflict, associated with the lack of participation in decision-making in the design and implementation of district policies (Thomasz, 2016; Zarlenga \& Marcus, 2014). This is also due to the fear from local residents of losing their neighbourhood's cultural identity, architectural and cultural heritage, and the beginning of a real estate speculation process; etc. (Thomasz, 2016; Zarlenga \& Marcus, 2014). The effect of these tensions and conflicts are the reactions of local organisations against the implementation of the creative regeneration policies. In many cases these reactions are based on the use of art as a tool of struggle or the creation of laws in defense of their interests. On the other hand, public administration seeks to correct the problems that opens up with residents and local organisations through projects and policies of social promotion and citizen participation. 
Culture is a tool for economic development, urban regeneration and social participation for creative regeneration policies. Within this framework, culture is understood as a sector of activity to be promoted (culture as arts and creative industries); as facilities for the attraction of talent (as public hubs for urban economic development); and as creativity (based on the idea of the sustainable development of cities that solve urban problems).

\section{Conclusion}

This article has examined the cultural policy strategies supporting urban regeneration, focusing on their particular characteristics in the Ibero-American context. We started by considering the circumstances in which these policies emerged in Europe in the 1980s, following the appearance in North America of a bottom-up logic of culturalist revaluation of urban space in the previous decade. We then ask ourselves to what extent the particularities that affect Ibero-American policies in this field have given rise in this cultural area to a peculiar approach to these policies, and what the Ibero-American experience brings to the understanding of the general phenomenon of urban cultural regeneration. In this sense, we suggested that what this experience highlights is the importance of taking into account the contexts, dynamics and processes, as essential determinants of the results of these policies. Likewise, in the face of the dominant vision of an ineluctably gentrifying urban cultural regeneration, based on the AngloSaxon experience, we also noted that the Ibero-American experience is more positive. Throughout the article, in the aim of clarifying these various issues, we first examined the most characteristic Iberian cases of urban cultural regeneration, comparatively inquiring about their common features. Then, we carried out a typological analysis of the Latin American experience, identifying, in this case, three main types of processes: patrimonial revitalisation, civic transformation and creative regeneration. What can we conclude, now this test has been completed?

In the first place, it should be noted that the complete transposition of the Iberian models to Latin America is nearly imposible, to the extent that in Latin America, due to the lower resources available to administrations, the emulation of strategies consisting of the creation of cultural flagships or the organisation of cultural mega-events has been unaffordable or counterproductive. Rio de Janeiro, which tried to erect a Guggenheim Museum, like Bilbao, between 1999 and 2005 and which later organised the Olympic Games, like Barcelona, in 2016, is proof of this because it did not reach its first goal and the results of his second bet were almost catastrophic. But beyond the discarded similarity in the typology of projects, the common starting specificities between the Iberian Peninsula and Latin America, and the intense exchange flows between them have determined the appearance of similar institutional mechanisms and the application of similar principles and tools in both areas.

We have seen that in both cases political decentralisation is the lever that opens the possibility and, in the context of the urban crisis (different in one and another), determines the emergence of the local entrepreneurial impulse, which tends to become embodied in a charismatic figure (such as the mayor of Barcelona, Pasqual Maragall, or the mayor of Bogotá, Antanas Mockus). All the regenerative schemes thus have a strong top-down bias, although with a greater or lesser private component, depending in the first place on the public resources available (in the case of the Iberian examples, a minor component, and in the case of the Latin American heritage revitalisation, a much higher one, according to Janoschka, Sequera and Salinas, 2014: 15), and secondly, the nature of the projects (civic transformation policies hardly need private partners, unlike those of creative regeneration).

On the other hand, mechanisms such as strategic planning have spread from Barcelona to Latin America (González, 2011: 19). This has undoubtedly contributed to the adoption of complex 
regeneration schemes across the whole area, in which the cultural elements are intertwined with others of urban or social functionality (something that happens in the Barcelona Model and in many of the operations of heritage revitalisation in Latin America), or adopt a polycentric approach (as also takes place in the Barcelona Model and similarly in the creative regeneration plan of Buenos Aires).

Factors such as those just mentioned favour a certain similarity in the approaches to cultural regeneration policies throughout the Ibero-American area. Of course, this does not translate into a specific Ibero-American approach. But at least we can say that there are some common features in the approaches of these policies across the whole area. The aforementioned tendency to adopt hybrid approaches, which combine the cultural and social, is one of them; and this can be related to the relatively weak autonomy of the cultural sphere within the area. Finally, the most distinctive feature could be the concern for participation and inclusion, very present in the Iberian examples analysed, notably in Barcelona, but also in Latin America, in the formula of heritage revitalisation, in the case of Quito, and, especially, in that of civic transformation (where the regenerative scheme comes to be sublimated in a mechanism of pure participation). This can be linked to the democratising character that culture-led urban regeneration policies have tended to have in Ibero-America, as we pointed out at the start of this article.

On the other hand, we also mentioned that the Ibero-American experience allows us to accredit the possibility of a positive cultural regeneration. And indeed, there are many successful experiences among the cases that we have considered here. As we have shown, those of Bilbao and Barcelona are clearly succesful experiences, in which the balance of the regenerative operations was extremely favourable, not only in economic but also in social and cultural terms. This is also the case in the Latin American civic transformation examined (Bogotá), in which the various actions carried out achieved very positive social effects, in particular greatly reducing the high levels of violence that existed in the city. On the other hand, concerning the cultural regeneration of neighbourhoods, in the Iberian cases discussed (those of El Raval and San Francisco), we have verified that, in spite of having experienced a certain degree of symbolic and commercial gentrification, they have both preserved social mixing and diversity and avoided any significant class displacement (Subirats and Rius, 2006; Rius, 2008; Gainza, 2017). The same can be said, in general, of the recovered city centres in Latin America, where until now only some commercial and symbolic transformations have been recorded (Janoschka, Sequera and Salinas, 2013: 4, 10).

In any case, the failed experiences of urban cultural regeneration have also proliferated in Latin America (from Valencia in Spain to Rio in Latin America) and this justly demonstrates the importance of contexts (political and economic) for the success or failure of operations, as well as the decisive nature of the processes, opened by definition. In fact, not even the success of a regenerative operation prevent subsequent negative drifts, as soon as the favourable contexts change or the virtuous formulas are altered. The experience of Barcelona proves this. In El Raval, the boom in the real estate bubble and the intensification of the turistification process in Barcelona have led to a tremendous increase in house prices in recent years, with a parallel decline in local population and a significant increase also in the Western foreign population and middle-income citizens settled there (Arbaci and Tapada-Berteli, 2012). Therefore, success in the long term is not guaranteed. On the other hand, after the Olympic Games, the Universal Forum of Cultures Project, which tried to continue its path, failed. Along the long and tortuous process of its definition and implementation (from 1996 to 2004) the cultural leadership from which the Project was initially formulated was supplanted by other, disparate and contradictory interests (political and economic). In this way, culture was relegated and instrumented 
(Mascarell, 2007: 114-5), so marking the point of the greatest distance from the original parameters of the Barcelona Model.

As we have seen, the Ibero-American experience offers some interesting clues for the analysis of culture-led urban regeneration policies, their potentialities and their possible failures. But this exploration that we have carried out here from the existing literature cannot be conclusive, since studies are still scarce, particularly in the Latin American area, and their methodologies are too disparate. While waiting for new works to broaden and improve the base for the analysis of the topic, from this regional perspective, it would be desirable that the attention be projected in the future also to other regional areas different from the Anglo-Saxon, so that the vision on this important chapter of current cultural policies is broadened and deepened. Hopefully this article will serve as a stimulus for this.

\section{References}

Arbaci, S, \& Tapada-Berteli, T. (2012). Social inequality and urban regeneration in Barcelona city centre: Reconsidering success. European Urban and Regional Studies, 19(3), 287-311.

Bell, M. , \& and Jayne, M. (2003) 'Design-led' urban regeneration: a critical perspective, Local Economy, 18(2), 121-134.

Betancur, J. J. (2014). Gentrification in Latin America: Overview and Critical Analysis. Urban Studies Research, 2014, 1-14. http://doi.org/10.1155/2014/986961

Bianchini, F., \& Parkinson, M. (1993). Cultural Policy and Urban Regeneration: The West European Experience. Cultural policy and urban regeneration: the West European experience. Manchester Univ Pr.

Blanco I (2009) Does a Barcelona model really exist? Periods, territories and actors in the process of urban transformation. Local Government Studies, 35(3), 355-369.

Boisier, S. (2004). Desarrollo territorial y descentralización. El desarrollo en el lugar y en las manos de la gente. Eure, 30(90), 27-40.

Cabrera Hanna, J. S. (2017). El Centro Histórico de Quito en la planificación urbana (19421992). Discursos patrimoniales, cambios espaciales y desplazamientos socio culturales. Territorios, (36), 189-215. http://doi.org/10.12804/revistas.urosario.edu.co/territorios/a.5249

Cameron, S.,\& Coaffee, J. (2005) Art, Gentrification and Regeneration - From Artist as Pioneer to

Public Arts, International Journal of Housing Policy, 5(1), 39-58.

Caraballo Perichi, C. (2001). Centro Históricos y actores sociales. Sustentabilidad versus imaginarios. En F. Carrión (Ed.), Centros Históricos de América Latina y el Caribe (pp. 329346). Quito: UNESCO.

Carrión, F. (2001a). Centros Históricos de América Latina y el Caribe. Quito: UNESCO.

Carrión, F. (2001b). Medio Siglo en el camino al tercer milenio: los centros históricos de América Latina. En F. Carrión (Ed.), Centros Históricos de América Latina y el Caribe (pp. 29-94). Quito: UNESCO.

Carrión, F. (2007). Financiamiento de los centros históricos de América Latina y el Caribe. Quito: FLACSO-Ecuador.

Castles, F. G. (ed.) (1993). Families of Nations. Patterns of Public Policy in Western Democracies. Aldershot: Dartmouth Publishing Company.

Chartrand, H. H., \& Mccaughey, C. (1989). The Arm's Length Principle and the Arts: An International Perspective - Past, Present and Future. En M. C. Cummings Jr. \& J. M. Davision Schuster (Eds.), Who's to Pay? for the Arts: The International Search for Models of Support (pp. 1-30). New York City: American Council for the Arts. 
Degen, M.,\& García, M. (2012). The Transformation of the Barcelona Model?: An Analysis of Culture, Urban Regeneration and Governance", International Journal of Urban and Regional Research, 36(5), 1022-1038.

Degen, M.,\& García, S. (2008). La Metaciudad: Barcelona. Transformación de una Metrópolis, Barcelona: Anthropos.

Del Cerro, G. (2006). Bilbao: Basque Pathways to Globalization. Amsterdam: Elsevier.

Dias Velarde, P. (2001). El espacio urbano en la recuperación del Centro Histórico de Lima. En

F. Carrión (Ed.), Centros Históricos de América Latina y el Caribe (pp. 347-364). Quito: UNESCO.

Evans, G. (2001). Cultural Planning. An urban renaissance?. London: Routledge.

Evans, G. (2003). Hard-Branding the Cultural City - From Prado to Prada. International Journal of

Urban and Regional Research, 27(2), 417-440.

Evans, G. (2005). Measure for measure: evaluating the evidence of culture's contribution to regeneration. Urban Studies, 42(5/6), 959-83.

Evans, G. (2009). Creative cities, creative spaces, and urban policy, Urban Studies, 46, 10031040.

Ferrer Viana, F. (2001). El paisatge urbà, un punt de trobada. Barcelona: Aula Barcelona.

Gainza, X. (2017). Culture-led neighbourhood transformations beyond the revitalisation/gentrification dichotomy. Urban Studies, 54(4), 953-970.

García, B. (2004). Cultural Policy and Urban Regeneration in Western European Cities: Lessons from Experience, Prospects for the Future. Local Economy, 19(4), 312-326.

Gomà, R. , \& Rosetti, N. (1998). Análisis de una política de regeneración urbana: El caso de ciutat vella. In: Brugue, Q, \& Gomà, R. (eds.). Gobiernos locales y políticas públicas. (pp. 56-98). Barcelona: Ariel.

Gómez, M.V. (1998). Reflective images: the case of urban regeneration in Glasgow and Bilbao. International Journal of Urban and Regional Research, 22(1), 106-21.

Gómez, M.V.,\& González, S. (2001). A reply to Beatriz Plaza's 'The Guggenheim-Bilbao Museum effect'. International Journal of Urban and Regional Research, 25(4), 898-900.

González, S. (2004). The role of the Guggenheim Museum in the development of urban entrepreneurial practices in Bilbao. International Journal of Iberian Studies, 16, 177186.

González, S. (2006). Scalar narratives in Bilbao: a cultural politics of scales approach to the study of urban policy. International Journal of Urban and Regional Research, 30(4), 836-57.

González, S. (2011). Bilbao and Barcelona «in motion». How urban regeneration «models» travel and mutate in the global flows of policy tourism. Urban Studies, 48(7), 1397-1418. http://doi.org/10.1177/0042098010374510

Grodach, C., Foster, N.,\& Murdoch III, J. (2014). Gentrification and the Artistic Dividend: The Role

of the Arts in Neighborhood Change, Journal of the American Planning Association, 80(1),

21-35.

Gutman, M. (2001). Del monumento aislado a la multidimensionalidad. En F. Carrión (Ed.), Centros Históricos de América Latina y el Caribe (pp. 95-106). Quito: UNESCO.

Hall, P. (1990). Cities of Tomorrow: An Intellectual History of Urban Planning and Design in the Twentieth Century. Oxford: Blackwell.

Harvey, D. (1989). From Managerialism to Entrepreneurialism: The Transformation in Urban Governance in Late Capitalism, Geografiska Annaler, 71(1), 3 - 17.

Hernández, T. (2013). La ciudad desde la cultura, la cultura desde la ciudad. Anuario Ininco, 25(1), 311-336.

Janoschka, M., Sequera, J., \& Salinas, L. (2014). Gentrification in Spain and Latin America - a 
Critical Dialogue. International Journal of Urban and Regional Research, 38(4), 1234-

1265. http://doi.org/10.1111/1468-2427.12030

Julier, G. (2000). The Culture of Design. London: Sage.

Julier, G. (2005). Urban designscapes and the production of aesthetic consent. Urban Studies, $42,869-887$.

Kanai, J. M., \& Ortega-Alcázar, I. (2009). The prospects for progressive culture-led urban regeneration in Latin America: Cases from Mexico City and Buenos Aires. International Journal of Urban and Regional Research, 33(2), 483-501. http://doi.org/10.1111/j.14682427.2009.00865.x

Lacarrieu, M. (2010). Ciudades latinoamericanas. Desafíos y limitaciones de los procesos de recualificación cultural: ¿̇globales/transnacionales, regionales, nacionales y/o locales? Revista PRAIAVERMELHA, 20(2), 135-156.

Landry, C. (2008). The Creative City: A Toolkit for Urban Innovators. London: Routledge.

Landry, C., \& Bianchini, F. (1998). The creative city. London: Demos.

Lash, Scott and Urry, John. (1994). Economies of Signs and Spaces. London: Sage.

Ley, D. (1996). The New Middle Classes and the Remaking of the Central City. Oxford: Oxford University Press.

Luque Azcona, E. J., \& Smith, H. (2010). Transformaciones, conflictos e identidades en el Centro Histórico de Salvador de bAHIA. Revista Computense de Historia de America, 36, 291-315. http://doi.org/10.5209/rev

Markusen, A.,\& Gadwa, A. (2010). Arts and culture in urban or regional planning: A review and research agenda. Journal of Planning Education and Research, 29(3), 379-391.

Marshall, T. (2004). Transforming Barcelona, Routledge: London.

Mascarell, F. (2007). Barcelona y la modernidad. La ciudad como proyecto de cultura. Gedisa: Barcelona.

Monclús, F. (2003). The Barcelona model: an original formula?, Planning Perspectives, 18(4), 399-421.

Montero, A. P., \& Samuels, D. (2004). The Political Determinants of Decentralization in Latin America: Causes and Consequences. Decentralization and Democracy in Latin America, 139. http://doi.org/10.1017/CBO9781107415324.004

Moreira Ortega, M. (2001). El Centro Histórico de Quito: un modelo mixto de gestión. En Centros Históricos de América Latina y el Caribe (pp. 253-274). Quito: UNESCO.

Mutual, S. (2001). Ciudades y centros históricos de América Latina y el Caribe. En F. Carrión M. (Ed.), Centros Históricos de América Latina y el Caribe (pp. 113-138). Quito: UNESCO.

d'Ovidio, M.,\& Rodríguez Morató, A. (2017). Against the creative city: Activism in the creative city:

When cultural workers fight against creative city policy, City, Culture and Society, 8: 3-

6.

Pasotti, E. (2012). Brecht in Bogotá: Urban Cultural Policy Transformed a Clientist Political

Culture. En C. Grodach (Ed.), The politics of urban cultural policy. Global perspectives (pp.

66-85). London: Routledge.

Plaza, B. (2008). On some challenges and conditions for the Guggenheim to be an effective economic re-activator, International Journal of Urban and Regional Research, 32, 506517.

Plaza, B, Tironi, M .\& Haarich, S.N. (2009). Bilbao's art scene and the "Guggenheim effect" revisited. European Planning Studies, 17(11), 1711-1729.

Plaza, B., \& Haarich, S.N. (2015). The Guggenheim Museum Bilbao: Between Regional Embeddedness and Global Networking, European Planning Studies, 23(8), 1456-1475.

Pratt, A. (2011). The cultural contradictions of the creative city. City, Culture and Society, 2(3), $123-$

130.

Ramalho, J. L. (2012). O papel da cultura na produçao de cidade: a Casa da Música no Porto. 
PhD Dissertation, Universidade de Lisboa.

Richards, G. (2015). Events in the network society: the role of pulsar and iterative events, Event Management, 19, 553-566.

Rius, J. (2008). Los barrios artísticos como base local de la cultura global. El caso del Raval de Barcelona", Revista Internacional de Sociología, LXVI(51), 179-205.

Rius, J. (2014). Culture and authenticity in urban regeneration processes: Place branding in central Barcelona. Urban Studies, 51(14), 3026-3045.

Rodríguez Morató, A. (2005). La reinvención de la política cultural a escala local: el caso de Barcelona. Sociedade e Estado, 20(2), 351-376.

Rodríguez Morató, A. (2008). La emergencia de una capital cultural europea. In: Degen M and García, S .(eds) La metaciudad: Barcelona. transformación de una metrópolis (pp. 4564), Barcelona: Antrophos.

Rodríguez Morató, A. (2012). The Culture Society: A Heuristic for Analyzing Cultural Change in the Global Age. En A. Sales (Ed.), Sociology Today: Social Trasnformation in a Globalazing World (pp. 316-338). United Kingdom: Sage Publications.

Rojas, E. (2001). Financiando la conservación del patrimonio urbano en América Latina y el Caribe: la acción del Banco Interamericano de Desarrolllo. En F. Carrión (Ed.), Centros Históricos de América Latina y el Caribe (pp. 15-22). Quito: UNESCO.

Ronda, S. (2000). Estrategias de legitimaciones y discursos: La utilización de las políticas de rehabilitación de los centros históricos. En F. Carrión (Ed.), Desarrollo cultural y gestión en centros históricos. (pp. 85-104). Quito: FLACSO-Ecuador.

Sánchez Belando, M. V., Rius Ulldemolins, J., \& Zarlenga, M. I. (2012). ¿Ciudad creativa y ciudad sostenible?: Un análisis crítico del modelo Barcelona de políticas culturales. Revista Crítica de Ciências Sociais, (99), 31-50.

Sant'Anna, M. (2001). El Centro Histórico de Salvador de Bahía: paisaje, espacio urbano y patrimonio. En F. Carrión (Ed.), Centros Históricos de América Latina y el Caribe (pp. 177198). Quito: UNESCO.

Sarfatti Larson, M. (1995). Behind the Postmodern Facade, Berkeley: University of California Press.

Scott, A. J. (2014). Beyond the Creative City: Cognitive-Cultural Capitalism and the New Urbanism. Regional Studies, 1-14.

Scott, A. J. (2000). The Cultural Economy of Cities. London: Sage.

Stern, M. J.,\& Seifert, S.C. (2010). Cultural clusters: The implications of cultural assets agglomeration for neighborhood revitalization. Journal of Planning Education and Research, 29(3), 262-279.

Subirats. J., \& Rius, J. (2006). Del Chino al Raval. Cultura y transformación social en la Barcelona central. Barcelona: CCCB.

Subirós, P. (ed.) (1993). El vol de la fletxa. Barcelona'92: Crónica de la reinvenció de la Ciutat. Barcelona: Electa.

Subirós, P. (1999). Estratègies culturals i renovació urbana. Barcelona: Aula Barcelona.

Thomasz, A. G. (2016). Los nuevos distritos creativos de la ciudad de Buenos Aires: La conversión del barrio de La Boca en el «distrito de las artes». Eure, 42(126), 145-167. http://doi.org/10.4067/S0250-71612016000200007

Vicario, L., \& Martinez Monje, P.M. (2003). Another 'Guggenheim effect'? The generation of a potentially gentrifiable neighbourhood in Bilbao. Urban Studies, 40(12), 23832400.

Yúdice, G. (2008). Modelos de desarrollo cultural urbano: ¿gentrificación o urbanismo social? Alteridades, 18(36), 47-61.

Zallo, R. (1995). Industrias y políticas culturales en España y País Vasco. Servicio Editorial UPV, Bilbao.

Zarlenga, M. I., \& Marcus, J. (2014). La cultura como estrategia de transformación urbana. Un 
análisis crítico de las ciudades de Buenos Aires y Barcelona. En M. Margulis, M. Urresti, \& H. Lewin (Eds.), Intervenir en la Cultura. Más allá de las políticas culturales (pp. 33-55).

Buenos Aires: Biblos.

Zukin, S. (1995). The Cultures of Cities. Oxford: Blackwell.

Zukin, S. (1982). Loft living: Culture and capital in urban change. Baltimore, MD: Johns Hopkins University Press.

Zulaika, J. (1997). Crónica de una seducción. El museo Guggenheim Bilbao. Madrid: Nerea. 